ACTA UIVERSITATIS CIBINIENSIS - TECHNICAL SERIES

Vol. LXV 2014

\title{
THE CLUSTERS - COLLABORATIVE MODELS OF SUSTAINABLE REGIONAL DEVELOPMENT
}

\author{
GABRIEL MĂNESCU \\ Scientific Research Department "Nicolae Bălcescu" Land Forces Academy, Sibiu, Romania, Faculty of \\ Engineering, “Lucian Blaga” University, Sibiu, Romania, manescug@yahoo.com \\ CLAUDIU KIFOR \\ Faculty of Engineering, “Lucian Blaga” University, Sibiu, Romania, claudiu.kifor@ulbsibiu.ro
}

\begin{abstract}
The clusters are the subject of actions and of whole series of documents issued by national and international organizations, and, based on experience, many authorities promote the idea that because of the clusters, competitiveness increases, the workforce specializes, regional businesses and economies grow. The present paper is meant to be an insight into the initiatives of forming clusters in Romania. Starting from a comprehensive analysis of the development potential offered by each region of economic development, we present the main types of clusters grouped according to fields of activity and their overall objectives.
\end{abstract}

Key words: Cluster, collaborative model, regional development.

\section{Introduction}

Analyzing the impact of the financial crisis on the global economies, financiers and economic analysts, on both sides of the Atlantic, found that the economic realities evolve much faster than the national/regional/international policies meant to combat its effects (Barroso, J.M., 2010).

In a time when, in many European countries, the economic and financial crisis was at its highest, the European leaders that met in Brussels in March 2010 established a new European strategy, known as Europe 2020. This is "a strategy that will help us to come out stronger from the crisis and turn the EU into a smart, sustainable and inclusive economy delivering high levels of employment, productivity and social cohesion" (Barroso, J.M., 2010).

Europe 2020 puts forward three mutually reinforcing priorities:

- smart growth - developing an economy based on knowledge and innovation; economy.

- sustainable growth - promoting a more resource efficient, greener and more competitive

- inclusive growth: fostering a high-employment economy delivering social and territorial cohesion (Europe 2020).

The strategy aims, in the short run, at combating the crisis, and, in the long run, in facilitating the creation of new jobs, at increasing the living standard and at placing the European Union at the top of international charts. The solutions regarding the crisis focus on social and green economy where prosperity is ensured through innovation, better use of resources and knowledge. The objective of the European Commission is to lead a Europe based on knowledge, on rapid and sustainable growth, and on social progress. One way to achieve this is by improving the cooperation between businesses, universities, research and state institutions, namely by a very popular, but insufficiently exploited form of partnership, the cluster. Defined by many experts by means of terms like, for example, research cluster, ICT cluster, innovative cluster or industrial cluster, this form of partnership is appearing more and more often in discussions and public debates (Dan, M.C., 2011). 


\section{Collaborative concepts: Industrial Park, Science and Technology Park, Business Networks, Cluster.}

2.1. The industrial park is a delimitated area where economic activities, activities of industrial production and services and activities of valorization of the scientific research and/or of technological development take place in specific facilities, in order to valorize the human and material potential of the area. It is based on the joint venture of the central and local government authorities, businesses, and other interested partners. The term of industrial park indicates an environment that is more attractive than the one that is usually provided by other industrial areas. Thus, no strict criteria of selection for the companies that will be members are imposed (Tanțău, A.D. 2011).

2.2. The science and technology parks develop a privileged relationship between universities and innovative companies, representing a starting point for the transfer of technology and the development of potential clusters. The science park is represented by an organization that provides space for sale or for rent to research -development departments or units. The science parks define strict rules in order to ensure an attractive environment for research (Tanțău, A.D. 2011).

2.3. The concept of technology park is similar to that of science park. In the case of the technology park there are fewer restrictive conditions for the potential users, and the relationships with universities or research institutions are not as strong as in the case of the science parks (J. Choi , Jang S. , K. Hog., 2008).

2.4. The networks of companies represent a form of collaboration between legally independent companies but with common economic interests and which are dispersed from a geographical point of view (Tanțău, A.D. 2011).

2.5. The concept of cluster is not new; it has a relatively long history and several names have been given to it: "competitiveness pole", "industrial district", "industrial agglomeration". Nowadays, the terms that are the most frequently used are those of "cluster" and "competitiveness pole" (France and Belgium), the most established term being that of "cluster (Guth, M., Coşniţă, D., 2010).

The simplest description of clusters is based on the description of supplier-customer relations and value-chain. Most companies buy "inputs" (raw materials, services, components) from other suppliers and incorporate them into their products that they sell to customers. The functioning of companies within an "industrial agglomeration" brings them a competitive advantage, because they have a dense network of suppliers and customers nearby (Guth, M., Coşniţă, D., 2010).

Regarding the syntagm "value chain", it derives from the conception of Alfred Marshall (18421924) who showed that a geographical concentration of a particular industrial sector determines the specialization of the suppliers. For example, in Northern Italy there are clusters made up of small companies that are specialized according to the various stages of the production process and between them there are coordination relations. (Bianchi, A., G. Gualtieri, 1987).

Regional scientists have improved Marshall's idea highlighting the advantage of companies that derives from geographical proximity, distinguishing between the two types of externalities: localization externalities (gains from the proximity to similar companies, especially of the same industry) and urbanization (gains from the proximity to companies in other industries) (MoI, 2009).

Currently, the most widely used definition of the cluster is given by the one who popularized this concept, Professor Michael Porter, "The clusters are geographic concentrations of companies and institutions that are interconnected, which operate in a particular field. The clusters comprise a group of related industries and other organizational entities that are important from the point of view of competition. These include, for example, suppliers of specialized inputs, such as components, machinery and services, and providers of specialized infrastructure. Clusters often extend downstream towards various distribution channels and customers and laterally towards manufacturers of complementary products and towards industries that are related through common skills, technologies or inputs." (Porter, M. 1998)

The definition of the cluster is found in the legislation of Romania: "a group of producers, users and/or beneficiaries, aiming to implement best practices in the EU in order to increase the competitiveness of economic operators" (HG 918/2006).

The clusters are characterized by a flexible organization, each member does certain activities, has a role established according to the strategy of the cluster and to the market requirements (Tanțău, A.D. 2011). The clusters have been seen as a tool for promoting and supporting competitiveness, innovation and growth at all levels (local, regional and national). In most of the cases, the initiative of getting associated in a cluster has influenced the business strategy, has improved its competitiveness because the 
provided added value has increased, and the authorities have rethought their public policies and have analyzed everything from the new perspective of the regional economy (Dan, M.C., 2011).

\section{The Situation of Clusters in Romania}

\subsection{Research Methodology}

The general objective of this paper is to identify the degree of implementation of the forming initiatives of clusters at national level.

As a consequence of this objective we start from the idea that the number of clusters and of the fields of activity, in which these act, is closely linked to the social and economic potential of each region of development. Thus, we have chosen a secondary analysis of data as a research method, so we were able to achieve a centralized situation of the regional potential for development of the clusters.

\subsection{Results}

The synthesized data (Table 1) are taken from the Statistical Yearbook of Romania 2011 (NIoS , 2012) (the data on higher education institutions, the number of researchers and the number of patent applications), the site of the Ministry of Industry (MoI,2013) (the number of industrial parks and clusters), the site of the Ministry of Regional Development and Public Administration (MRDPA, 2013) (data on the regional structures and Strategies/regional development plans for the 2014-2020 period, posted on the sites of the regional development agencies), the RO INNO Romania website, an initiative of The National Authority for Scientific Research (NASR) meant to support the consolidation and the development of innovation and technology transfer at national level and from the Catalogue "The National Network for Innovation and Technology Transfer" (RO INNO, 2013), the 2008 edition, a publication funded by NASR. The National Network for Innovation and Technology Transfer ReNITT) consists of innovation and technology transfer entities accredited by NASR, which conduct services of knowledge and technology transfer services in order to support the social-economic development through innovation and technology transfer, in order to increase the degree of valorization of the results of research in economy, in order to improve the competitiveness of SMEs.

Table 1: Summary of the regional potential for cluster development

\begin{tabular}{|l|c|c|c|c|c|c|c|c|c|}
\hline & $\begin{array}{c}\text { North- } \\
\text { West }\end{array}$ & Center & $\begin{array}{c}\text { North- } \\
\text { East }\end{array}$ & $\begin{array}{c}\text { South- } \\
\text { East }\end{array}$ & $\begin{array}{c}\text { Bucureși } \\
\text { - Ilfov }\end{array}$ & $\begin{array}{c}\text { South- } \\
\text { Muntenia }\end{array}$ & $\begin{array}{c}\text { Soth- } \\
\text { West }\end{array}$ & West & TOTAL \\
\hline No. of counties & 6 & 6 & 6 & 6 & 2 & 7 & 5 & 4 & $41+\mathrm{Buc}$ \\
\hline No. of towns & 42 & 57 & 46 & 33 & 10 & 48 & 40 & 42 & \\
\hline Universities & 16 & 13 & 14 & 7 & 37 & 4 & 4 & 13 & 108 \\
\hline $\begin{array}{l}\text { Research } \\
\text { institutes and } \\
\text { centers }\end{array}$ & 7 & 3 & 11 & - & 79 & 2 & 3 & 7 & 112 \\
\hline $\begin{array}{l}\text { Industrial } \\
\text { parks* }\end{array}$ & $7 / 1 \mathrm{~A}$ & $16 / 1 \mathrm{~A}$ & $3 / 1 \mathrm{~A}$ & $2 / 1 \mathrm{~A}$ & 4 & $\begin{array}{c}17 / 3 \mathrm{GF} ; \\
1 \mathrm{~A}\end{array}$ & 2 & $2 / 1 \mathrm{~A}$ & $\begin{array}{c}53 / 3 \mathrm{GF} ; \\
6 \mathrm{~A}\end{array}$ \\
\hline $\begin{array}{l}\text { Innovation and } \\
\text { technology } \\
\text { transfer entities } \\
\text { within NNITT, } \\
\text { out of which: }\end{array}$ & 8 & 5 & 2 & 2 & 24 & 2 & 4 & 5 & 52 \\
\hline $\begin{array}{l}\text { - science and } \\
\text { technlogy parks }\end{array}$ & - & - & 1 & 1 & 1 & - & - & 1 & 4 \\
\hline $\begin{array}{l}\text { - technlogy and } \\
\text { business } \\
\text { incubators }\end{array}$ & 1 & 2 & - & - & 9 & 1 & 2 & 1 & 16 \\
\hline $\begin{array}{l}\text { - tehnological } \\
\text { information centres }\end{array}$ & 3 & 3 & 1 & 1 & 6 & 1 & 2 & 2 & 19 \\
\hline $\begin{array}{l}\text { - tehnology } \\
\text { transfer centres }\end{array}$ & 4 & - & - & - & 8 & - & - & 1 & 13 \\
\hline $\begin{array}{l}\text { No. of } \\
\text { researchers }\end{array}$ & 2457 & 2027 & 3190 & 1029 & 11398 & 1321 & 1701 & 2299 & 25489 \\
\hline $\begin{array}{l}\text { No. of patent } \\
\text { applications }\end{array}$ & 132 & 106 & 260 & 81 & 585 & 94 & 78 & 89 & 1425 \\
\hline No. of clusters & 6 & 12 & 5 & 3 & 7 & 1 & 4 & 4 & 42 \\
\hline
\end{tabular}


* the numerator is the total number of industrial parks and the denominator is the number of industrial parks that are being built (A) or Greenfield (GF)

As one can easily notice, the development of the clusters fits the theoretical models, in the sense that the cluster development initiatives are more present in regions with more numerous urban population concentrations, which benefit from the amenities offered by the industrial parks and which take advantage of the scientific expertise of the universities in the area. It is true that the creation and development of a cluster cannot be done without the involvement of firms with an innovative potential in the area. A review of these entities is almost impossible due to their large number and to the industrial sector to which they belong. The geographical distribution of the clusters is shown in Fig. 1.

Figure 1: The geographical distribution of the clusters

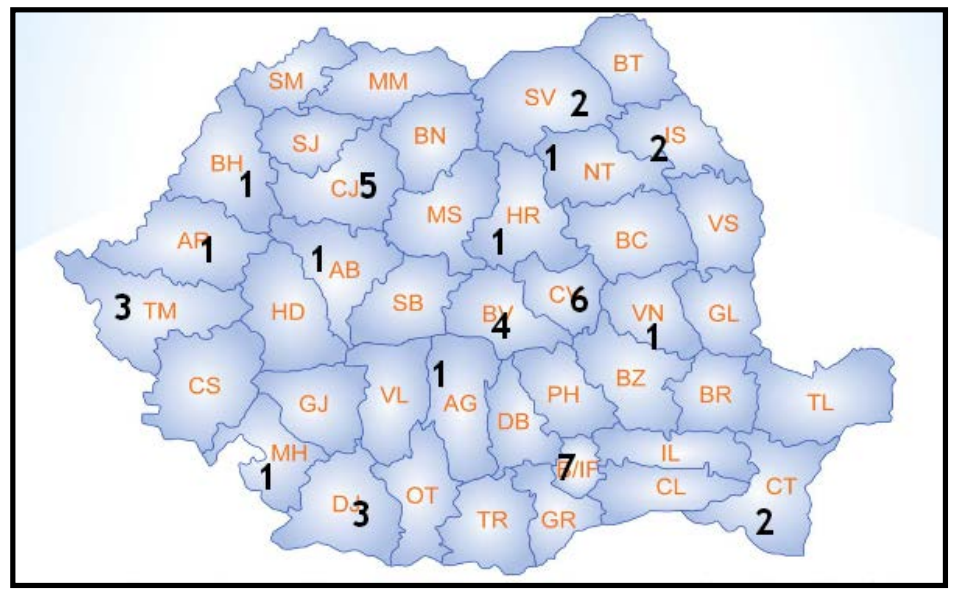

Source: Ministry of Industry, 2013

The number of clusters in each field of activity is shown in Table 2.

Table 2: The number of clusters in each field of activity

\begin{tabular}{|c|l|c|}
\hline No. & \multicolumn{1}{|c|}{ Field of activity } & No. of clusters \\
\hline $\mathbf{1}$ & Automotive & 6 \\
\hline $\mathbf{2}$ & Information technology & 3 \\
\hline $\mathbf{3}$ & Wood processing & 2 \\
\hline $\mathbf{4}$ & Tourism & 5 \\
\hline $\mathbf{5}$ & Renewable energy & 4 \\
\hline $\mathbf{6}$ & Agricultural - food & 2 \\
\hline $\mathbf{7}$ & Textiles - Footwear & 4 \\
\hline $\mathbf{8}$ & Furniture & 2 \\
\hline $\mathbf{9}$ & Aviation and Aerospace & 2 \\
\hline $\mathbf{1 0}$ & Electric - Electronics & 3 \\
\hline $\mathbf{1 1}$ & Water produced energy & 1 \\
\hline $\mathbf{1 2}$ & Agricultural engineering & 1 \\
\hline $\mathbf{1 3}$ & Green energy & 1 \\
\hline $\mathbf{1 4}$ & Maritime & 1 \\
\hline $\mathbf{1 5}$ & Creative engineering & 1 \\
\hline $\mathbf{1 6}$ & Services & 2 \\
\hline $\mathbf{1 7}$ & Mecatronics & 1 \\
\hline $\mathbf{1 8}$ & Integrated autonomous systems & \\
\hline & & 1 \\
\hline
\end{tabular}


Studying the websites of the clusters in our country (we have to mention that not all the clusters have a website), these entities have a number of formulated objectives which usually address:

-the close cooperation between the cluster members;

-exchange of knowledge and ideas;

-public-private partnership;

-supporting research - for the benefit of all the member organizations and with an impact on society as a whole.

\section{Conclusions}

About the realism of the assumed objectives, the number of projects and the degree of their implementation, the cluster management and not least the sustainability of the clusters in Romania, we cannot give an opinion, because both the cluster policies and programs and the clusters as an innovative entity, require a period of maturation in order for a serious assessment of their economic impact to be made.

Another very important aspect is the fact that in Romania there is no cluster specialized in the field of defense, public order and national security, despite the fact that both military higher education institutions and companies in the national defense industry benefit from a huge scientific potential and a technological one respectively. The locations of business within the national defense industry, of the military higher education institutions and of the civilian universities could be a contributing factor for the initiation of such clusters, of course with the support of central and local authorities .

From our point of view, such a cluster could contribute to the economic re-launching of the defense industry, would contribute to the development of the collaboration relations between the higher education military/civilian institutions and the local authorities, and not least, would have a significant impact on the economic local/regional environment.

\section{References}

- Barroso,J.M., (2010) Preface, Communication from the Commission - EUROPE 2020, available at

http://eur-lex.europa.eu/LexUriServ/LexUriServ.do?uri=COM:2010:2020:FIN:RO:PDF, retrieved on 06.07.2013

- Bianchi, A. , G. Gualtieri. (1987) The External Growth of Through Merger and Aquisition: The Italian Experience, 1983-1986, Bologna: Nomisima.

- Choi J., Jang S., Hog K. (2008) From Bureaucratic Mode of Technological Entrepreneurship to Clustering Mode of Technological Entrepreneurship: Daedeok Science Park, Korea, in Carayannis E.,G., Assimakopoulos D., Kondo M.(Ed.) Innovations Networks and Knowledge Clusters, Palgrave Macmilan, UK, p.330-342

- Dan, M.C.,(2012) Clusterele inovative: o soluţie pentru dezvoltarea economică a României, Economie teoretică şi aplicată Vol. XIX, No. 9(574), p. 3-14, available at http://store.ectap.ro/articole/771_ro.pdf, retrieved on 06.07.2013

- European Commission (2010), Europe 2020, available at http://eurlex.europa.eu/LexUriServ/LexUriServ.do?uri=COM:2010:2020:FIN:RO:PDF， retrieved on 06.07.2013

- Guth, M., Coşniţă, D.,(2010) Clusters and Potential Clusters in Romania, Mapping Report, available at http://www.minind.ro/presa_2010/iulie/MappingReport_230710.pdf, retrieved on 16.07.2013

- Hotărârea Guvernului nr. 918/2006 pentru aprobarea Programului de stimulare a cercetării, dezvoltării şi inovării - IMPACT, available at http://lege5.ro/Gratuit/ha3tgnbs/hotararea-nr-9182006-pentru-aprobarea-programului-de-stimulare-a-cercetarii-dezvoltarii-si-inovarii-impact, retrieved on 10.07.2013

- Ministry of Industry, (2009) Ghid pentru implementarea în România a conceptului de cluster inovativ. available at http://www.minind.ro/presa_2010/iulie/ghid_230710.pdf, retrieved on 10.07.2013

- Ministry of Industry, (2013) Harta parcurilor industriale şi a clusterelor din România, available at http://www.minind.ro/reindustrializare/pdf/parcuri_industriale_si_clustere.pdf, retrieved on 10.07.2013 
- Ministry of Regional Development and Public Administration, The Regional structures and Strategies available at http://www.mdrt.ro/ and http://www.inforegio.ro/ro/ retrieved on 10.08.2013

- National Institute of Statistics, Anuarul statistic 2011, available at http://www.insse.ro/cms/ro/ content/anuarul-statistic-2011, retrieved on 10.07.2013

- Porter, M. (1998) Clusters and the new economics of competition, Harvard Business Review; Boston; Nov/Dec.

- RO INNO, Catalogul Reţeaua Naţională de Inovare şi Transfer Tehnologic, available at http://www.roinno.ro/index.php?module=info\&page=articol\&art_id=48, retrieved on 20.08.2013

- Tanţău, A. D., (2011) Ghid de bună practică pentru clustere şi reţele de firme, Bucureşti: Print Grup, available at http://www.inmaita.ro/2_Ghid_buna_practica_pentru_clustere_si_retele_de_firme.pdf, retrieved on 08.07.2013 